DOI https://doi.org/10.15589/znp2020.4(482).8

УДК 656.71072(045).

\title{
AUTOMATED METHODS OF CHECKING IN PASSENGERS AND BAGGAGE IN THE AIRPORT GROUND HANDLING SYSTEM
}

\section{АВТОМАТИЗОВАНІ СПОСОБИ РЕССТРАЦЇ̈ ПАСАЖИРІВ І БАГАЖУ В СИСТЕМІ НАЗЕМНОГО ОБСЛУГОВУВАННЯ АЕРОПОРТУ}

\author{
Denys V. Medynskyi \\ medynskyi_denys@ukr.net \\ ORCID: 0000-0002-8081-8712 \\ Dasha L. Maliarenko \\ dashamaliarenko@ukr.net \\ ORCID: 0000-0002-0410-3977
}

\author{
Д. В. Мединський, \\ аспірант
}

Д. Л. Маляренко, аспірантка

\author{
National Aviation University, Kyiv \\ Національний авіаційний університет, м. Київ
}

\begin{abstract}
An important role for increasing the competitiveness of airports is reflected in the increase in operational efficiency in the time dimension the system of ground handling of aircraft at the airport. Improving the efficiency of aircraft ground handling operations will reduce preparation time between aircraft flights, increase airline availability and increase airport capacity. During the formation of a flight plan, airlines want to reduce the time spent aircraft on the ground in order to increase the time of their effective use. The level of expenses for payment services related to ground handling of aircraft is $15-19 \%$ in the total volume of airlines expenses and directly affects the level of aviation tariffs. The purpose of the research is to systematize the time for handling 1 passenger in accordance with the methods of ground handling of aircraft at the airport.

Reducing cost and increasing the competitiveness of enterprises is possible only through the creation of a ground handling system for aircraft at the airport, which unites the work of all airport services in accordance with the requirements of the daily flight plan.

The lack of scientific developments and methodological recommendations on the formation of a ground handling system for passengers at the airport as a subsystem that ensures the internal logistics of the airport and work with the participation of the interaction of participants in the service process has led to the need to write this article in the field of effective use of time for servicing passengers, subject to operational management of transportation processes. The efficiency of passenger service at the airport in the aircraft ground handling system will improve the movement of ground service flows, reduce financial costs, increase profit and efficiency in the airports operations.

On how the ground handling of aircraft is organized depends on the safety of flights, the capacity of the airport, the regularity of aircraft departures, which ensures the main principle of the internal logistics of the airport - timeliness. During the development of the planning schedules, it is difficult for the airport to take into account various external factors that further cause difficulties in the activities of the aircraft ground handling agents.

The methodology for organizing the interaction of airport services is based on the theory of aircraft schedules, mathematical statistics and the theory of random variables. An analysis of the work of the service indicates that analytical procedures take a certain amount of time in the work of a passenger service agent, which in turn, require prompt solutions, especially during malfunctions, emergency situations and during ground handling. Making decision in conditions of complexity of work leads to violation of organizational and technological regulations of work.

The use of mathematical methods for the operational management of ground handling at the airport, the introduction of a decision support system for the production activities of the production and dispatch service will significantly increase the level of safety and regularity of flights, reduce the aircraft parking time, subject to prompt service and due to the clear interaction of airport services, which in general, will significantly increase the functionality of the ground handling system at the airport. In addition, the issue of optimizing the number of agents for servicing passengers during different types of boarding of passengers on the plane will have a significant impact and will increase the improvement of technical and economic indicators in the operation of the software for flight documentation intended for ground handling of aircraft.

Results. The concept of building a system of integrated operational management of ground handling in the work of a passenger service agent is proposed, which consists in a clear interaction of airport services and airlines, united into
\end{abstract}


a logistics system on the principles of marketing, management and logistics, which unlike existing systems, allows taking into account the influence of external and internal factors of the functioning of airports in order to reduce the risks of emergencies and failure situations.

A comprehensive program for accounting, processing and analysis of data on the effective use of the working time of an aircraft ground handling agent has been developed.

Key words: method; passenger service; flow chart; restrictions; ground handling; baggage; departure area; airport.

Анотація. Велику роль для підвищення конкурентоздатності аеропортів відіграє підвищення експлуатаційної ефективності в часовому вимірі - система наземного обслуговування повітряних суден в аеропортах. Підвищення ефективності експлуатаційних процесів наземного обслуговування повітряних суден знизить час на міжпольотну підготовку повітряних суден, підвищить працездатність авіакомпаній і збільшить пропускну здатність аеропорту. Під час формування планів авіарейсів, авіакомпанії прагнуть скоротити час перебування повітряного судна на землі з метою збільшення часу їхнього ефективного використання. Рівень витрат на оплату послуг, пов'язаних із наземним обслуговуванням повітряних суден, становить 15-19 \% у загальному об'ємі витрат авіакомпаній i, безперечно, впливає на рівень авіаційних тарифів.

Метою дослідження постає систематизація часу на обробку одного пасажира відповідно до методів наземного обслуговування повітряних суден в аеропорту.

Зниження витрат і підвищення конкурентоздатності авіапідприємств можливе тільки завдяки створенню системи наземного обслуговування повітряних суден, які об'єднують роботу всіх служб аеропорту відповідно до вимог добового плану польотів.

Брак наукових розробок і методичних рекомендацій із формування системи наземного обслуговування пасажирів в аеропорту як підсистеми, яка забезпечувала б внутрішню логістику аеропорту та роботу з урахуванням взаємодії учасників процесу обслуговування, зумовив потребу написання статті у сфері ефективного використання часу на обслуговування пасажирів за умови оперативного управління процесами перевезень. Ефективність обслуговування пасажирів в аеропорту в системі наземного обслуговування повітряних суден дасть змогу поліпшити рух наземних потоків обслуговування, знизити фінансові втрати, підвищити прибутки та ефективність у діяльності аеропорту.

Від того, як зорганізовано наземне обслуговування повітряних суден, залежать безпека польотів, пропускна здатність аеропорту, регулярність відправлень повітряних суден, що забезпечує основний принцип внутрішньої логістики аеропорту - своєчасність. Під час розроблення графіків планування в роботі аеропорту складно врахувати різні зовнішні чинники, які надалі спричиняють труднощі в діяльності роботи агентів із наземного обслуговування повітряних суден.

Методика організації взаємодії служб аеропорту базується на теорії розкладу руху повітряних суден, математичній статистиці та теорії випадкових величин. Аналіз роботи служби вказує на те, що в роботі агента з обслуговування пасажирів значний час становлять аналітичні процедури, які потребують оперативного розв'язання, особливо в разі збійних, позаштатних ситуацій, під час наземного обслуговування. Ухвалення рішень в умовах складності роботи призводить до порушення організаційно-технологічних регламентів роботи.

Застосування математичних методів оперативного управління наземним обслуговуванням в аеропорту, впровадження системи підтримки ухвалення рішень до виробничої діяльності виробничо-диспетчерської служби дадуть змогу суттєво підвищити рівень безпеки та регулярності польотів, скоротити час стоянки повітряного судна, за умови оперативного обслуговування та завдяки чіткій взаємодії служб аеропорту, що, загалом, значно збільшить функціонування системи наземного обслуговування в аеропорту. Крім того, суттєвої ваги додають питання оптимізації кількості агентів з обслуговування пасажирів під час різних видів посадки пасажирів до літака, збільшать поліпшення техніко-економічних показників у роботі програмного забезпечення з рейсової документації, призначених для наземного обслуговування повітряних суден.

Результати. Запропоновано концепцію побудови системи комплексного оперативного управління наземного обслуговування в роботі агента з обслуговування пасажирів, яка полягає а чіткій взаємодії служб аеропорту та авіакомпаній, об'єднаних у логістичну систему на принципах маркетингу, менеджменту та логістики, що дають змогу, на відміну від наявних систем, враховувати вплив зовнішніх і внутрішніх факторів функціонування аеропортів із метою зменшення ризиків виникнення позаштатних і збійних ситуацій.

Розроблено комплексну програму обліку, обробки та аналізу даних ефективного використання робочого часу агента з наземного обслуговування повітряних суден.

Ключові слова: метод; обслуговування пасажирів; технологічна схема; обмеження; наземне обслуговування; багаж; зона вильоту; аеропорт. 


\section{ПОСТАНОВКА ЗАДАЧІ}

Обслуговування пасажирів містить у собі такі технологічні операції: огляд пасажирів, багажу та ручної поклажі, міграційний та митний контроль, реєстрацію квитків, оформлення багажу та ручної поклажі пасажирів за класами обслуговування, комплектацію багажу за напрямками та рейсами, паспортний контроль, супровід та посадка пасажирів до повітряного судна, транспортування та завантаження багажу до повітряного судна, зустріч та супровід пасажирів, які прибули, обслуговування транзитних пасажирів, вивантаження 3 літака та транспортування багажу до місця видачі на транспортері. Агенти 3 обслуговування пасажирів безпосередньо задіяні в процесах наземного обслуговування повітряних суден i, цей процес $є$ достатньо складним через велику кількість персоналу виконуючих технологічні операції, тому потребує об'єктивного контролю, координації та оперативного управління.

Система автоматизованого управління технологічними процесами в аеропорту (далі - САУТПА) призначена для автоматизації управління технологічними процесами в аеропорту з метою підвищення комерційного завантаження рейсів, підвищення рівня культури. В обслуговуванні пасажирів та якості контролю за роботою служб наземного обслуговування. До завдань САУТПА як підсистеми входить: технологічне обслуговування повітряних суден, оперативне управління підготовкою до рейсу, управління комплектуванням пасажирського завантаження рейсів, управління інформаційним табло в аеропорту, розрахунок відомості з центрування. Характерною ознакою вищеназваних підсистем $є$ перевага інформаційно-довідкових функцій, а задачі у прийнятті рішень виокремлені несуттево. Важливим компонентом автоматизованих систем $є$ математичне забезпечення. В автоматизованих системах управління повітряним транспортом найбільше розповсюдження отримали статистичні та оптимізаційні моделі, які грунтуються за допомогою апарату дослідження операцій на транспорті.

Так у роботі пропонується розглянути сценарій виробничої діяльності служби наземного обслуговування з огляду на час доби в роботі агентів з обслуговування пасажирів для визначення потрібних ресурсів аеропорту.

\section{АНАЛІЗ ОСТАННІХ ДОСЛІДЖЕНЬ І ПУБЛІКАЦІЙ}

Питанню надання процесів 3 обслуговування пасажирів в аеропорту та аналізу причин порушення технологічної роботи наземного обслуговування [1] приділено багато уваги як вітчизняних, так і закордонних науковців, а саме: С.А. Кропівенцева, Т.В. Сорокіна, Ю.А. Радаєва, Д.А. Новіков, О.В. Коннікова, Ф. Саєг, Ф. Чарльз.
Наприклад, у роботі [2] авторка пропонує виокремити позаштатні ситуації в роботі критичного шляху.

У роботі [3] авторка розглядає базові технології для процесу обслуговування пасажирів за допомогою «Ідентифікації» пасажира у системі DCS для внутрішнього користування в межах зони аеропорту.

\section{МЕТА ДОСЛІДЖЕННЯ}

Систематизувати час на обробку однієї пасажирогодини у відповідності до методів наземного обслуговування.

\section{ОСНОВНИЙ МАТЕРІАЛ}

\section{1. Технологія наземного обслуговування паса-} жирів

На повітряних лініях цивільної авіації і зарубіжних авіакомпаній застосовуються три основні методи наземного обслуговування: основний, спрощений та аеробусний (рис. 1).

Найбільш поширений - це основний метод. У цьому випадку пасажир, що прибув в аеропорт, реєструє квитки й оформлює багаж в аеровокзалі. Після закінчення реєстрації здійснюється групова посадка пасажирів у літак. Багаж, що здається пасажирами в аеровокзалі, комплектується до рейсу і завантажується в багажні відсіки літака відповідно до центрувального графіку. Основний метод обслуговування характерний для повітряних ліній значної протяжності [4]. Його перевага в тому, що він забезпечує більше зручностей для пасажирів. Вони звільняються від багажу в аеровокзалі й доставляються до літака транспортом, а хибою є велика тривалість виконання операцій порівняно з іншими методами.

Основний метод може виконуватися за трьома технологічними схемами: по рейсовий, вільний, змішаний.

Порейсовий - технологічна схема передбачає виділення одного-двох робочих місць в операційному залі для кожного рейсу, де і виконується реєстрація пасажирів і приймання багажу. Ця схема виключає надходження багажу пасажирів не за призначенням і звільняє від необхідності включати до технології обслуговування ряд складних операцій. Хиба схеми - наявність черг на окремі робочі місця. Реєстрація пасажирів на літаки середньої пасажиромісткості проводиться на одному робочому місці, а на літаках великої пасажиромісткості (100 пасажирів і більше) на двох робочих місцях. Кожне робоче місце при по рейсовій системі реєстрації обслуговується двома співробітниками служби перевезення: черговим реєстратором та представником авіахендлінгу.

Вільна технологічна схема надає пасажиру можливість реєструвати квиток та здавати багаж біля будь-якого робочого місця в операційному залі. За цієї схеми відбувається ускладнення процесу обробки багажу за рейсами. Водночас цей метод допомагає найбільшою мірою механізувати процеси обробки 


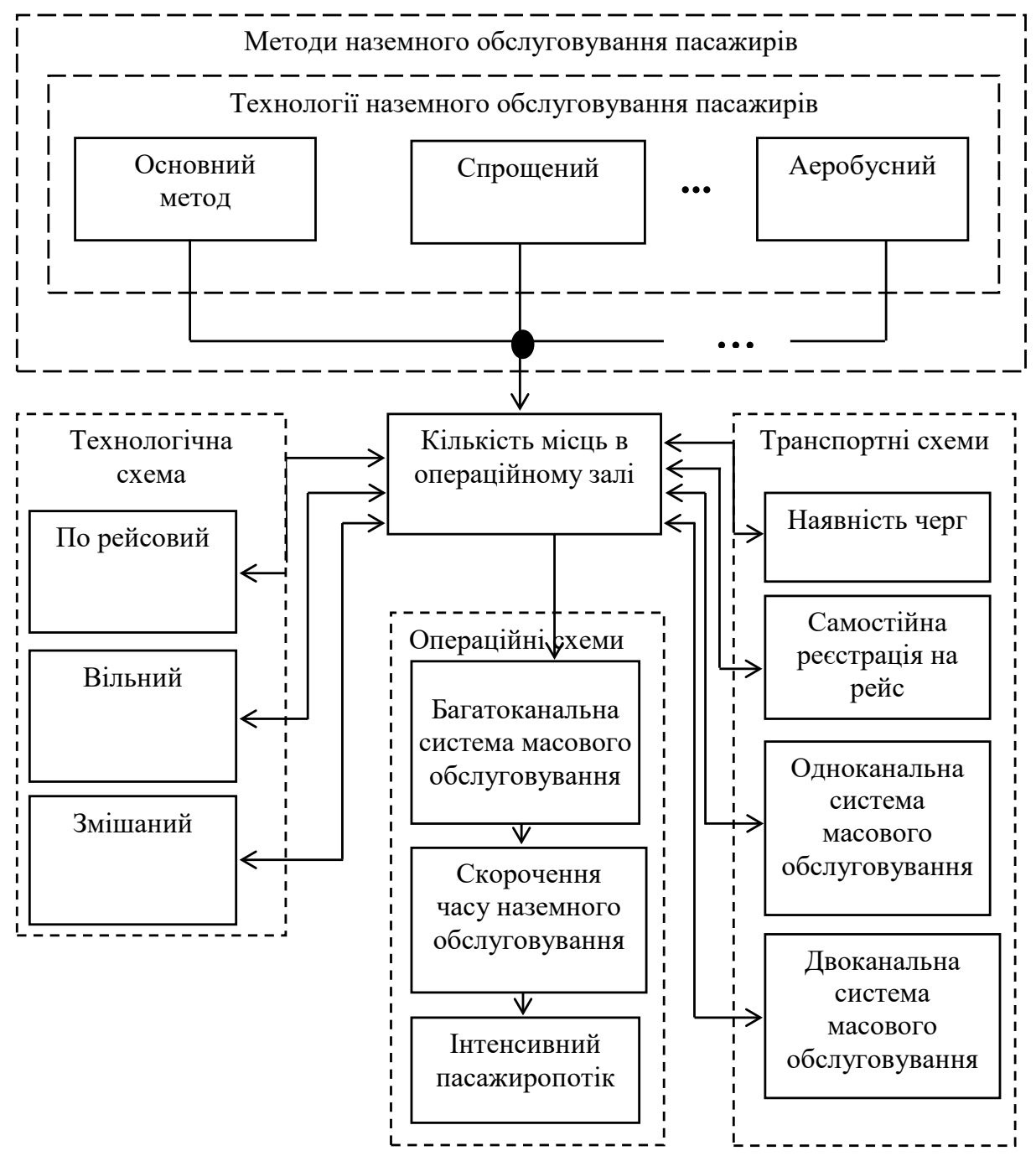

Рис. 1. Структурна схема автоматизованої системи контролю пасажирів рейсу, що відлітає

i скоротити час на наземне обслуговування пасажирів [5]. Хиба методу полягає в тому, що пасажир, який прибув до аеровокзалу незадовго до закінчення реєстрації, може стати в черзі за пасажирами більш дальніх рейсів і не встигне оформити квиток.

Комплектування багажу за даною схемою здійснюється після попереднього сортування багажу за рейсами. Час на його комплектування близько 45 хв. Початок транспортування багажу до літака передбачається обома схемами приймання за 10-12 хв до вильоту літака за розкладом. Супроводження багажу до літака і передача його черговому агенту з центрування літака здійснюється безпосередньо на пероні в місцях стоянки літаків. Завантаження багажу в багажні відсіки літака має закінчуватися одночасно 3 посадкою пасажирів.

Спрощений метод полягає в тому, що реєстрація пасажирів і оформлення багажу здійснюється не в аеровокзалі, а на аванпероні або безпосередньо біля трапу літака. Цей метод поширений на лініях серед- ньої і малої протяжності і може використовуватися на рейсах без проміжної посадки. Перевагою цього методу є значне скорочення часу наземного обслуговування, а недоліком - відсутність комфорту в обслуговуванні пасажирів.

Аеробусний метод характерний для повітряних ліній $з$ інтенсивним пасажиропотоком і підвищеною частотою руху літаків. В аеропортах, працюючих за цим методом, пасажири купують квиток заздалегідь перед польотом через систему бронювання. Це перспективний метод обслуговування пасажирів отримав широке розповсюдження за кордоном.

2. Технологічна схема обслуговування пасажирів, що відлітають

Оформлення цієї категорії відбувається в аеровокзалі аеропорту або інших спеціально призначених для цього спорудах, оснащених необхідним обладнанням, засобами механізації і зв'язку [6].

В аеропорту розміщуються засоби зв'язку та інвентар: тягач або електротягач 3 потягом контей- 
нерних візків для доставки багажу пасажирів; завантажувально-розвантажувальна рампа; контейнери; причіпний навантажувач контейнерів; автобуси (авто потяги) для доставки пасажирів до літака; стійки для реєстрації з присвоєними номерами; електронні ваги для зважування багажу і ручної поклажі; покажчики рейсів біля диспетчерської стійки виходів на перон i біля трапів літака; переговірний пристрій, переносні радіостанції; електрокари для доставки великогабаритного багажу до літака.

Каси для оплати за перевезення багажу понад встановленої норми перевезення бажано розміщувати близько біля зони реєстрації. Приміщення для обслуговування пасажирів, що відлітають має складатися 3 наступних зон: обслуговування пасажирів, оформлення багажу, спеціального контролю, комплектування багажу, очікування посадки. Площа зони комплектування багажу визначається за умови розміщення засобів механізації для його обробки. В операційних зонах обслуговування пасажирських аеровокзалів встановлюються диспетчерські та касові стійки. Диспетчерські стійки бувають восьми типів і призначені для наступних цілей: реєстрації квитків, оформлення бага жу черговими з реєстрації пасажирів, що вилітають; організації робочого місця диспетчера служби транзитних рейсів, що здійснює комплектування пасажирського завантаження на рейси і обслуговування транзитних пасажирів; організації робочого місця чергового довідкового бюро, агента 3 обслуговування пасажирів і відвідувачів аеровокзалів [7].

Касові стійки призначені для виконання касових операцій з оформлення квитків та оплати за перевезення багажу. Технічна характеристика і номенклатура комплектуючого обладнання наведені в табл. 1.

У таблиці 1 наведено перелік робіт, які необхідно виконати для оформлення пасажира, що відлітає, а також вказана тривалість робіт та послідовність їх виконання [8].
На рис. 2 показано мережевий графік, який описує дії агента з оформлення пасажира рейсу, що відлітає. Мережеві графіки побудовані за допомогою середовища VBA Excel.

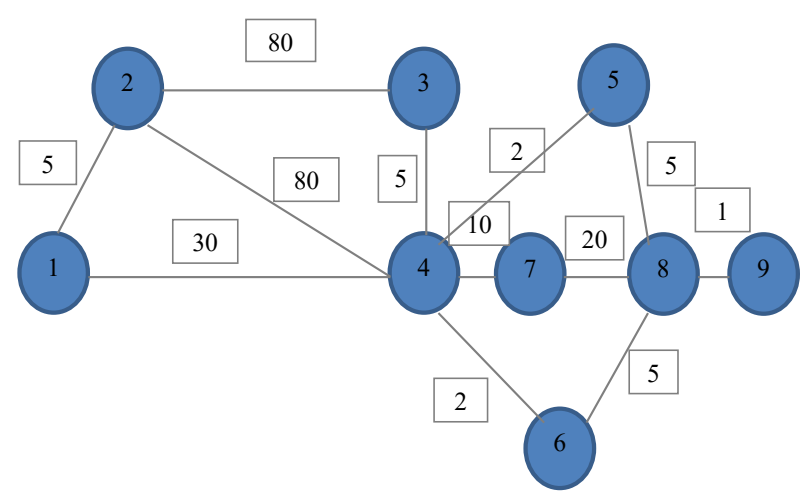

\section{Зображення вихідного графу}

Рис. 2. Мережева модель обслуговування пасажирів, які відлітають

Критичний шлях складають роботи: (1,2)-(2-3)-(3,4)-(4,7)$(7,8)-(8,9)$

Найбільший пріоритет робіт: (1,2),(2,3),(3,4),(4,7),(7,8), $(8,9)$.

Конструкція диспетчерських стійок і кас обслуговування забезпечує зручність спілкування з пасажиром, раціональне розміщення робочої документації, засобів місцевого освітлення і спеціального обладнання.

Площа зони очікування розраховується виходячи 3 норм площі на одного пасажира 0,7 м². Зона очікування обладнується меблями для сидіння 100-300 ос. і має окремий вихід на аванперон.

Реєстрація квитків та оформлення багажу пасажирів може здійснюватися на одному або двох робочих місцях. Перед початком реєстрації квитків робітники служби організації перевезень, відповідальні

Таблиця 1. Список робіт з обслуговування пасажирів, які відлітають

\begin{tabular}{|c|c|c|c|c|c|}
\hline Шифр & Назва роботи & Після роботи & \multicolumn{2}{|c|}{$V_{i} V_{j}$ коди робіт } & $\begin{array}{l}d_{i} \text { час виконан- } \\
\text { ня операцій }\end{array}$ \\
\hline $\mathrm{O}$ & Підготовка до реєстрації & - & 1 & 2 & 5 \\
\hline A & Реєстрація пасажирів & $\mathrm{O}$ & 2 & 3 & 80 \\
\hline $\mathrm{B}$ & Комплектування багажу & $\mathrm{O}$ & 2 & 4 & 80 \\
\hline $\mathrm{C}$ & Комплектування харчування & - & 1 & 4 & 30 \\
\hline $\mathrm{D}$ & Підсумки реєстрації. Центрувальний графік & A & 3 & 4 & 5 \\
\hline $\mathrm{E}$ & Доставка і завантаження багажу в ПС & $\mathrm{A}, \mathrm{B}, \mathrm{D}$ & 4 & 5 & 20 \\
\hline $\mathrm{F}$ & Завантаження в ПС бортхарчування & $\mathrm{A}, \mathrm{D}$ & 6 & 6 & 20 \\
\hline G & Контроль виходу пасажирів & $\mathrm{D}$ & 4 & 7 & 10 \\
\hline $\mathrm{H}$ & Доставка і посадка пасажирів в ПС & $\mathrm{G}$ & 7 & 8 & 20 \\
\hline $\mathrm{I}$ & Прийом та передача багажу. Оформлення документації & $\mathrm{E}$ & 5 & 8 & 5 \\
\hline $\mathrm{J}$ & $\begin{array}{l}\text { Зняття-дозавантаження борт харчування. Оформлення } \\
\text { документів }\end{array}$ & $\mathrm{F}$ & 6 & 8 & 5 \\
\hline $\mathrm{K}$ & Передача перевізної документації на рейс & $\mathrm{H}, \mathrm{I}, \mathrm{J}$ & 8 & 9 & 10 \\
\hline
\end{tabular}




\section{АВТОМАТИЗАЦІЯ ТА КОМП'ЮТЕРНО-ІНТЕГРОВАНІ ТЕХНОЛОГІЇ № 4〜 2020}

за оформленні даного рейсу, готують до виконання наступні операції. Черговий $з$ реєстрації: отримує відомості про кількість проданих квитків на рейс; встановлює на стійці показник рейсу і засвідчується у вірності даних світлового табло; підготовлює відомість реєстрації [9].

Прийомоздавач багажу підготовлює: багажні відомості в трьох екземплярах для кожного пункту розвантаження, в яких вказує номер рейсу, дату вильоту, тип і номер літака, аеропорт розвантаження та завантаження; багажні бірки і бірки «в кабіну». Він також проставляє в багажній відомості для кожного пункту розвантаження номера бірок, які будуть прикріплені на перші прийняті місця багажу, і перевіряе справність транспортерів та іншого обладнання, наявність необхідних транспортних засобів.

Завантажувач багажу готує ярлики на контейнери, вказуючи в них номер контейнерів, дату відправлення, номер рейсу і аеропорт призначення, пломби.

Чергові з огляду пасажирів перед початком його проведення повинні: перевірити стан приміщення зони спец контролю - санітарний стан, наявність і справність зачинення дверей через, які слідують пасажири на посадку, і впевнитися в тому, що ці двері закриті та можливість безконтрольного виходу iз зони виключена; перевірити технічну справність апаратури, яка застосовується при огляді; підготувати систему ПЗ для обліку пасажирів, що проходять на посадку через зону спеціального контролю.

Не пізніше ніж за 15 хв до початку реєстрації на рейс старший диспетчер організації перевезень дає вказівку групі перонної механізації про подачу комплексу пустих контейнерів і електрокари до місця комплектування багажу на рейс. Вільні контейнери переміщуються завантажувачем на механізовану рампу. Суміщення рівнів візків і рампи при перевантаженні контейнерів досягається за допомогою вертикального переміщення підйомного стола рампи.

За 60 хв до вильоту літака, диспетчер служби організації перевезень дає дозвіл на оголошення про початок і місце проведення реєстрації. В тексті оголошення вказується номер рейсу, аеропорт призначення, номер стійки або секції реєстрації. При наявності в аеропортах інформаційних табло, ці дані передаються в систему інформації [10].

Досконалість технології обслуговування пасажирів, що відлітають полягає в пошуку пришвидшити виконання робіт, які становлять критичний шлях.

Скорочення тривалості реєстрації забезпечує впровадження автоматизованої системи відправки та автоматизації робіт з внутрішньо вокзального сортування багажу. Відкриття додаткових стійок реєстрації також суттєво пришвидшить реєстрацію на рейс [11].
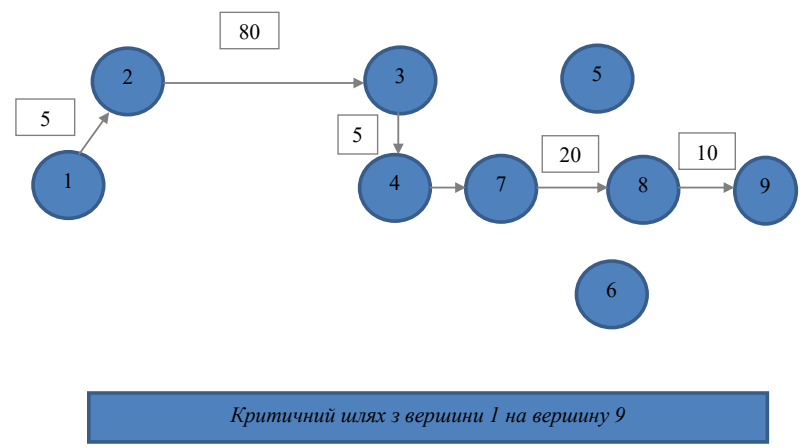

Рис. 3. Критичний шлях мережевої моделі обслуговування пасажирів, що відлітають

Реєстрація квитків і оформлення речей (багажу i ручної поклажі) пасажирів починається за одну годину і закінчується за 20 хв до відправлення літака. Послідовність і час виконання операцій, склад бригади, що задіяний в процесі обслуговування пасажирів і обробки багажу, наведені в табл. 2.

Таблиця 2. Виконання операцій з обслуговування рейсу

\begin{tabular}{|c|c|}
\hline Операції & Склад бригади \\
\hline $\begin{array}{l}\text { Доставка пустих } \\
\text { контейнерів в зону ком- } \\
\text { плектування багажу }\end{array}$ & Водій тягача \\
\hline $\begin{array}{l}\text { Підготовка до реєстрації і } \\
\text { спец контролю квитків }\end{array}$ & $\begin{array}{l}\text { Черговий з реєстрації, при- } \\
\text { йомоздавач багажу, заванта- } \\
\text { жувач, черговий з огляду }\end{array}$ \\
\hline $\begin{array}{l}\text { Реєстрація білетів і оформ- } \\
\text { лення багажу }\end{array}$ & $\begin{array}{l}\text { Черговий з реєстрації, при- } \\
\text { йомоздавач багажу, заван- } \\
\text { тажувач }\end{array}$ \\
\hline Спец контроль пасажирів & Чергові із спец контролю \\
\hline $\begin{array}{l}\text { Пломбування контейнерів, } \\
\text { завантаження на візки }\end{array}$ & $\begin{array}{l}\text { Прийомоздавач багажу, за- } \\
\text { вантажувач, водій тягача }\end{array}$ \\
\hline $\begin{array}{l}\text { Транспортування } \\
\text { контейнерів до літака, } \\
\text { подача засобів перонної } \\
\text { механізації до літака }\end{array}$ & Водій тягача \\
\hline $\begin{array}{l}\text { Підведення підсумків } \\
\text { реєстрації, оформлення } \\
\text { документації }\end{array}$ & $\begin{array}{l}\text { Черговий з реєстрації, при- } \\
\text { йомоздавач багажу, заван- } \\
\text { тажувач }\end{array}$ \\
\hline Посадка пасажирів у літак & Чергові з посадки \\
\hline $\begin{array}{l}\text { Завантаження контейнерів } \\
\text { в літак }\end{array}$ & $\begin{array}{l}\text { Бригада з перонної } \\
\text { механізації, водій тягача }\end{array}$ \\
\hline $\begin{array}{l}\text { Буксирування та запуск } \\
\text { двигунів }\end{array}$ & Командир ПК \\
\hline
\end{tabular}

Під час реєстрації квитків та оформлення речей робітники служби перевезень (РСП) виконують такі операції.

Агент хендлінгу: отримує від пасажира квиток і перевіряє його відповідність до рейсу, що оформлюється; зважує речі пасажира (багаж і ручну поклажу); записує дані багажу та ручної поклажі до системи; заповнює багажні бірки та прикріплює їх до дійсних 
місць багажу, а до речей, дозволеним до перевезення в салоні літака, бірки «до кабіни»; знімає багаж із ваг і ставить його на транспортер; передає квиток та відривні талони багажних бірок черговому з реєстрації.

Черговий з реєстрації: отримує квиток, перевіряє правильність і повноту його заповнення; заносить дані до «Відомості реєстрації відправлення пасажирів і багажу» відомості про пасажира, масу ручної поклажі, багажу, масу платного багажу, кількість місць, номери багажних бірок; проставляє у діалоговому вікні реєстрації навпроти порядкового номера рядка в розділі «Пасажири» цифру «1», а в розділах «Багаж» і «Ручна поклажа» відповідні дані про масу речей пасажирів, оформлених для перевезення; вилучає талон квитка (попередньо переконавшись в наявності на зворотному боці його необхідних даних про пасажира), повертає йому квиток і направляє до пункту спеціального контролю [12] (рис. 4).

Вантажник знімає 3 транспортера-накопичувача кожне місце багажу і вкладає в контейнер до його заповнення, не допускаючи ушкодження багажних бірок та упаковки цілісності багажу. Також вантажник записує дані про кожен контейнер на ярлику, початковий та кінцевий номери багажних бірок.

Комплектування починається 3 контейнера, що розміщений на поворотному столі. Великогабаритний багаж комплектується на електрокарі для наступного розміщення в хвостовому вантажному відсіку літака. Для його оформлення застосовуються бірки іншого кольору.

Після закінчення реєстрації, робітниками РСП підводяться підсумки і оформлюються відповідні документи [13].

Черговий $з$ реєстрації: отримує відомості від завантажувача багажу про номери першої і останньої багажних бірок по кожному контейнеру і проводить підрахунок маси багажу по контейнерам; проводить підсумки у відомості реєстрації, завіряє своїм підписом і особистим штампом правильність занесених даних; повідомляє масу багажу кожного контейнера прийомоздавачу для заповнення багажної відомості; передає старшому диспетчеру РСП підсумки реєстрації для включення в зведену відомість і складання центрувального графіка.

Відомості про наявність вільних місць в літаку по закінченню реєстрації черговий передає диспетчеру групи.

Прийомоздавачу багажу записує в багажній відомості рейсу, що відправляється: номера контейнерів; дані по кожному контейнеру (кількість місць багажу, номери першої та останньої багажної бірки, масу контейнера 3 багажем); дані про багаж (кількість місць, номера бирок, масу), що перевищує встановлені розміри (за масою або габаритами), що перевозиться не в контейнерах. В графі «Усього» він вказує кількість місць багажу, кількість і масу контейнерів з багажем.

Під час дотримання ПС з посадками в проміжних пунктах багаж, що призначений для розвантаження в різних аеропортах, розміщується в окремих контейнерах. На кожний аеропорт виписується окрема багажна відомість.

Вантажник багажу: передає черговому 3 реєстрації відомості про номера першої і останньої бірок багажу по кожному контейнеру; закриває і опломбовує кожний контейнер в передбаченому для цього місці; заповнює ярлик кожного контейнера, в якому вказує кількість місць багажу, масу багажу, масу брутто контейнера, розписується на ярлику і вкладає його в спеціальний карман для перевізної документації.

Підсумкові дані про реєстрацію пасажирів і масі кожного контейнера з багажем передаються старшому черговому (диспетчеру) для включення у відомість і складання центрувального графіку.

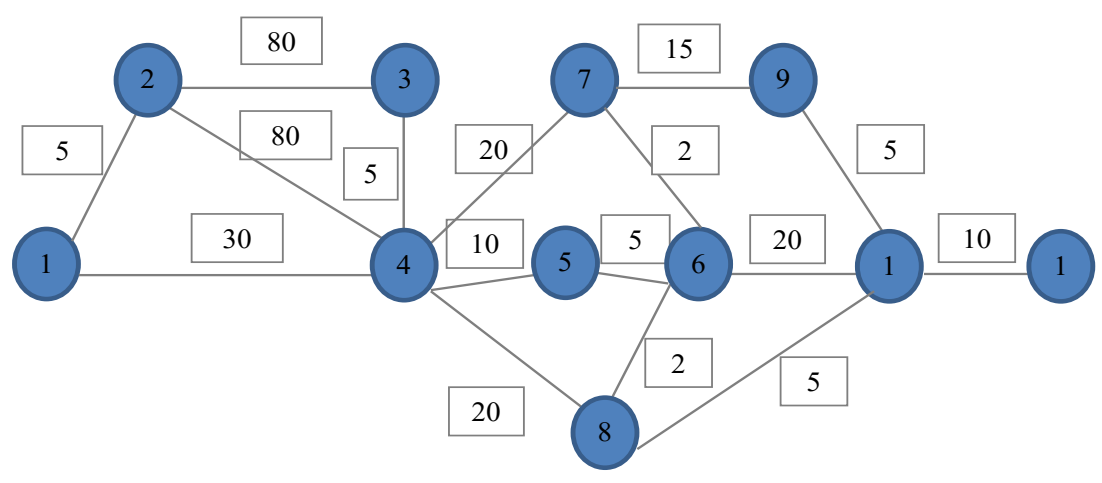

Зображсння вихідного графу

Pис. 4. Мережева модель обслуговування в разі неявки пасажира на посадку 


\section{АВТОМАТИЗАЦІЯ ТА КОМП'ЮТЕРНО-ІНТЕГРОВАНІ ТЕХНОЛОГІЇ № 4〜 2020}

Для забезпечення безпеки польотів, охорони життя, здоров'я пасажирів і членів екіпажу в аеропортах, міських аеровокзалах проводиться спеціальний контроль пасажирів, їх багажу і ручну поклажу для виявлення предметів і речовин, що заборонені до перевезення транспортом. Огляд здійснюється в обладнаних зонах спеціального контролю в будівлях аеровокзалу або приміщеннях в порядку, що викладений в інструкції про проведення спеціального контролю.

Спеціальний контроль пасажирів і їх речей закінчується не пізніше, ніж за 15 хв до вильоту, що $\epsilon$ i часом припинення допуску пасажирів на посадку в літак. Перонний контролер (черговий з огляду) по завершенню встановленого часу: закриває вхідні двері в зону спец контролю; сповіщає диктору (операторам інформаційно-довідковій групі) про закінчення посадки в літак на даний рейс, щоб сповістити про це по гучномовцю і включення відповідних табло і покажчиків. Черговий з посадки перед входом в зону спеціального контролю за пасажирами уточнює в чергового з реєстрації кількість зареєстрованих пасажирів на даний рейс, номер літака, номер його стоянки та інші необхідні дані. За 25-30 хв до вильоту літака диспетчер служби організації перевезень отримує дозвіл на посадку пасажирів в літак (рис. 5).

Критичний шлях, величина якого визначає загальну тривалість робіт, становить 140 хвилин.

Про початок посадки в літак пасажири сповіщаються за допомогою радіомовлення, інформаційних табло або інших засобів інформації, після чого вони в супроводі чергових 3 посадки направляються до літака або доставляються автобусом (в залежності від місця стоянки літака) [14].

Після закінчення посадки пасажирів у літак черговий із посадки:

- уточнює кількість пасажирів, що перебувають на літаку;

- запрошує в диспетчера (старшого чергового) РСП через рацію про пасажирів, що не з'явилися на посадку у встановлений час. Якщо пасажири, які запізнилися на посадку, прибули до зачинення дверей за розкладом, то черговий, упевнившись у проходженні ними спеціального контролю, забезпечує їх посадку на літак. Речі цих пасажирів розміщуються в кабіні літака;

- вносить зміни в зведено-завантажувальну відомість, відмічає в ній час закриття дверей і передає члену екіпажу;

- у встановлений час дає дозвіл на буксирування бортового трапу.

Опломбовані контейнери встановлюються вантажниками на транспортні засоби в порядку їх завантаження в літак. Транспортування багажу в контейнеpax до літака здійснюється після установки всіх контейнерів 3 багажем на причепи і закінчення спеціального контролю пасажирів. Контейнери обов'язково супроводжуються прийомоздавачем багажу, який передає їх і документацію стюарду.

Під час прийому контейнерів від прийомоздавача, бортпровідник перевіряє наявність і справність пломб на кожному з них; отримує три екземпляри багажної відомості, перевіряе їх заповнення і тотожність записів в багажній відомості і на ярликах; розписується в трьох екземплярах багажної відомості і повертає третій екземпляр прийомоздавачу, а перший і другий залишає в себе.

Завантаження контейнерів в літак здійснюється персоналом в складі бригадира-оператора, вантажника і водія тягача. У разі затримки рейсу контейнери з багажем зберігаються в місцях, спеціально обладнаних для цих цілей. Встановлювати контейнери в процесі зберігання один на одного забороняється.

Процеси перед польотного обслуговування рейсу описані технологічними графіками робіт,які в свою чергу регламентують структуру робіт та послідовність їх виконання, але на жаль не забезпечують час виконання.

Застосування мережевих моделей в службі наземного обслуговування пасажирів дозволить поліпшити

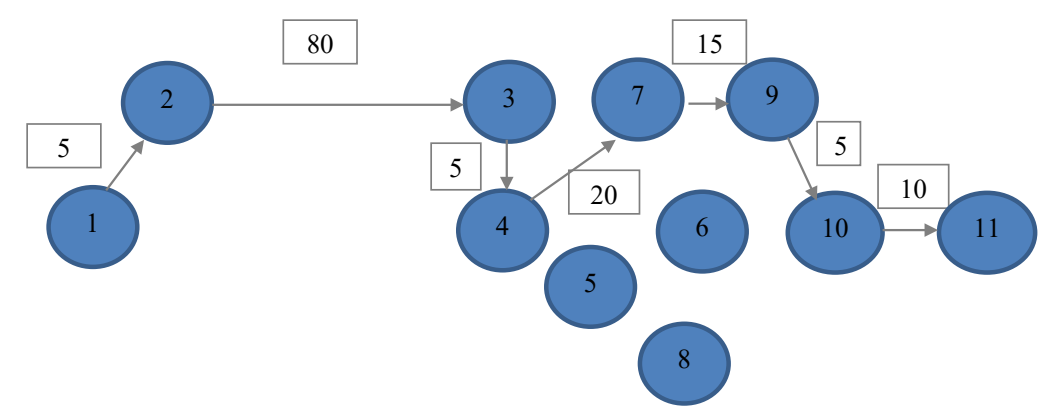

Критичний шияхх з вершини 1 на вершину 11

Рис. 5. Критичний шлях моделі з обслуговування в разі неявки пасажира на посадку 
та удосконалити технології оптимізації робочого часу агентів з обслуговування.

Для порівняльного аналізу пропонується порівняння системи пасажирів рейсу, що прилетів відповідно до технологічної схеми з обслуговування.

3. Технологічна схема обслуговування пасажирів, що прилітають

У процесі підготовки до розвантаження багажу 3 літака, який прилетів (табл. 3) необхідно: своєчасно сповістити робітників зміни служби організації перевезень про майбутній приліт ПС і про кількість багажу, що слідує до даного аеропорту; призначити відповідального прийомоздавача багажу і вантажника; виділити необхідні навантажувально-розвантажувальні механізми і транспортні засоби (тягач з візком, електрокари, автомашини і т.д.); забезпечити вчасне прибуття до стоянки літака обслуговуючого персоналу з вивантаження контейнерів. Від літака пасажири в супроводі чергових із зустрічі і посадки доставляються на автобусі або слідують пішки до споруди аеровокзалу в зону видачі багажу.

В аеропорту призначення, вивантаження контейнерів 3 літака починається одразу після завершення бригадою роботи двигунів (з дозволу екіпажу ПК) і здійснюється бригадою перонної механізації. Передача контейнерів $з$ багажем прийомоздавачу аеропорту призначення здійснюється бортпровідником літака після їх вивантаження, який передає прийомоздавачу багажну відомість, присутній при вивантаженні контейнерів з літака і при їх огляді, у випадку пошкодження пломб присутній до кінця видачі багажу пасажирам і при необхідності бере участь у складанні від- повідних актів. Під час прийому контейнерів від бортпровідника прийомоздавач багажу ретельно оглядає пломби контейнерів, переконується в цілісності їх кріплення і правильності відтисків, звіряє відповідні записи на ярликах з даними багажної відомості; всі порушення в оформленні документів фіксується в графі «Службові відмітки» багажної відомості.

Якщо контейнери справні i нема порушень в оформленні ярликів, то прийомоздавач підписує багажні відомості. За невідповідності кількості контейнерів даним багажної відомості, відсутності або порушенні пломб та інших несправностей він разом з бортпровідником складає відповідний акт. Вивантажені із літака контейнери доставляються водіями транспортних засобів до місця видачі багажу і встановлюються вантажниками на рольганги стрічкового транспортера. В процесі вивантаження контейнера прийомоздавач багажу перевіряє відповідність кількості місць багажу із записами на ярлику і в багажній відомості [15].

Багаж вручну виймається вантажником із контейнера і встановлюється на транспортер, що доставляє багаж у зону видачі його пасажирам. Останні самі отримують багаж і прямують до виходу із зони видачі багажу.

\section{ОБГОВОРЕННЯ ОТРИМАНИХ РЕЗУЛЬТАТІВ}

Критичний шлях становлять роботи $(1,2)-(2,3)-$ $(3,4)-(4,7)-(7,9)-(9-10)-(10-11)$, це є ознакою того, що від початку до закінчення кожного виду робіт залежить загальна тривалість обслуговування пасажирів, що очікують на виліт, оскільки неможливо затримувати початок виконання кожної з робіт, так само як

Таблиця 3. Обслуговування ПС після прильоту й вильоту

\begin{tabular}{|c|c|}
\hline Операції & Механізми і обладнання \\
\hline \multicolumn{2}{|c|}{ Літак, що вилітає } \\
\hline $\begin{array}{c}\text { Доставка контейнерів до зони комплектування багажу і } \\
\text { установка їх на завантажувальну рампу. } \\
\text { Завантаження багажу в контейнери. }\end{array}$ & $\begin{array}{c}\text { Малогабаритний тягач з під’їздом контейнерних візків. За- } \\
\text { вантажувально-розвантажувальна рампа. Контейнери. }\end{array}$ \\
\hline $\begin{array}{c}\text { Пломбування контейнерів і заповнення ярлика на кожен } \\
\text { контейнер, оформлення багажної відомості. }\end{array}$ & Тягач. \\
\hline $\begin{array}{c}\text { Перезавантаження завантажених контейнерів на } \\
\text { транспортні засоби і їх фіксування. }\end{array}$ & $\begin{array}{l}\text { Тягач. Контейнерні візки. Контейнери. } \\
\text { Завантажувач контейнерів. }\end{array}$ \\
\hline Доставка контейнерів до літака. Завантаження контейнерів & Тягач. Візки. \\
\hline у літак. & Контейнери. \\
\hline \multicolumn{2}{|c|}{ Літак, ццо прилетів } \\
\hline $\begin{array}{c}\text { Вивантаження контейнерів з борту літака на транспортний } \\
\text { засіб. }\end{array}$ & Завантажувач контейнерів. Тягач. Візки. Електрокар. \\
\hline Доставка контейнерів до місця видачі багажу пасажирів. & Тягач. Візок. Завантажувально-розвантажувальна рампа. \\
\hline \multicolumn{2}{|l|}{$\begin{array}{c}\text { Перезавантаження контейнерів з транспортного засобу на } \\
\text { рампу. }\end{array}$} \\
\hline $\begin{array}{l}\text { Відкриття контейнерів, вивантаження багажу з контейнерів } \\
\text { і установка його на транспортер. Перевірка відомостей, що } \\
\text { вказані на ярлику. }\end{array}$ & Транспортер видачі багажу. \\
\hline \multicolumn{2}{|c|}{ Отримання багажу. } \\
\hline Доставка порожніх контейнерів в зону комплектування. & Тягач. Візки. \\
\hline
\end{tabular}




\section{АВТОМАТИЗАЦІЯ ТА КОМП'ЮТЕРНО-ІНТЕГРОВАНІ ТЕХНОЛОГІЇ № 4 2020}

і збільшувати їх тривалість. Високий пріоритет із дотримання моменту початку та закінчення робіт мають роботи:

- підготовка до реєстрації;

- реєстрація пасажирів;

- передача підсумків реєстрації;

- доставка та завантаження багажу до ПС;

- ідентифікація та зняття місць багажу;

- приймання та передача багажу із оформленням документації;

- передача перевізної документації.

У разі неявки зареєстрованого пасажира на рейс на посадку, загальна тривалість обслуговування пасажирів, що відлітають збільшується на 10 хвилин і в підсумку становить 140 хвилин. Момент закінчення робіт $з$ передачі перевізної документації зміститься на 10 хвилин, що безпосередньо має вплив на час вильоту літака 3 аеропорту. Тому закінчення обслуговування пасажирів, що відлітають в обумовлені строки можливе лише за рахунок здійснення технологічних операцій зі скорочення тривалості робіт критичного шляху $(1,2)-(2,3)-(3,4)-(4,7)-(7-9)-(9-10)-$ (10-11). Варто прагнути до скорочення тривалості робіт з доставки та завантаження багажу до ПС $(4,7)$, а також з виявлення та зняття зареєстрованого багажу пасажира, який не з'явився на посадку $(7,9)$.

\section{ВИСНОВКИ}

Застосування методів управління з обслуговування пасажирів у системі наземного обслуговування дасть змогу структурувати процес шляхом декомпо- зиції та поділу його на етапи, завдання, підзавдання й отримати надалі мережеву модель, знайти роботу критичного шляху, здійснити перерозподіл ресурсів, контролювати ресурси.

Аналіз процесу обслуговування пасажирів, що відлітають із застосуванням методів наземного обслуговування дозволяє виявити та своєчасно контролювати найбільш відповідальні кроки в роботі агента 3 обслуговування пасажирів, які мають виконуватися у послідовності одна за одною, а тривалість цих робіт визначатиме автоматичний процес обслуговування.

Поліпшення процесу обслуговування повинно впливати не лише на зміну технології в обслуговуванні, але й на скорочення тривалості робіт з обслуговування тих пасажирів, що відлітають. Завдання оптимального розподілу ресурсів під час зміни тривалості робіт із урахуванням додаткових робіт з ліквідацією факторів затримки вильоту рейсу також є актуальною в сьогоденні. У тому разі, коли є безліч комбінацій тривалості та вартості робіт, кожна 3 комбінацій може автоматично видати різний час затримки та вартості усього процесу з обслуговування пасажирів, які відлітають

Процедура вибору компромісного співвідношення між тривалістю та вартістю у виконанні технологічних робіт з наземного обслуговування має на меті співставлення такої технології з обслуговування, яка, зі свого боку, забезпечила б мінімальні витрати за умови заданої тривалості процесу обслуговування однієї пасажирогодини в аеропорту.

\section{REFERENCES}

[1] Andronov A.M., Chyzhniak A.N. (1977). Mathematical methods of planning and management of production and economic activities of civil aviation enterprises. Moscow. 215 p.

[2] Babaskyi V.V., Korolkova M.A. (2011). Ways to improve the efficiency of the airline. Saint Petersburg. 80 p.

[3] Belenkyi A.S. (1992). Research of operations in transport systems: ideas and schemes of planning optimization methods. Moscow.

[4] P. Buslenko V.N. (1977). Automation of simulation of complex systems. Moscow. 239 p.

[5] Horlach L.V. (1990). Development of methods and algorithms for operational control of the process of preparing aircraft for flight: abstract dissertation of candidate of technical sciences. Lenyngrad.

[6] Kanarchuk V.E., Chygrynets A.D., Lenchevskyi V.N. (1987). Air transportation service facilities. Directory. Kyiv. 136 p.

[7] Koliasnykov V.A. (2004). Improvement of the technology of functioning of ground services to ensure the trouble-free operation of the airport new enterprise: abstract dissertation of candidate of technical sciences. Saint Petersburg. 24 p.

[8] Kuklev E.A. (1998). Methods of mathematical modeling of systems. Saint Petersburg. 116 p.

[9] Lysytsyn V.S., Smyrnov N.N., Chyniuchyn U.M. (1985). Automation of production processes of technical operation of aircraft. Moscow. 248 p.

[10] Lytvynenko A.E. (1988). Modeling of production processes in automated control systems of civil aviation. Tutorial. Kyiv. $72 \mathrm{p}$.

[11] The principles of organizing the loading and unloading of aircraft. IATA. (1991). $230 \mathrm{p}$.

[12] Rezer. S.M. (1985). Interaction of transport systems. Moscow. 246 p.

[13] Rusynov I.A. (1971). Mechanization of ground handling of air transportation. Moscow. 252 p.

[14] Sovetov B.IA., Yakovlev S.A. (1985). System Modeling: Textbook for universities in the specialty «Automated control systems». Moscow. $271 \mathrm{p}$.

[15] Organization of airport ground services management. Theoretical foundations of optimization of functioning. Tutorial. (1983). $75 \mathrm{p}$. 


\section{СПИСОК ВИКОРИСТАНОЇ ЛІТЕРАТУРИ}

[1] Андронов А.М., Хижняк А.Н. (1977). Математические методы планирования и управления производственно-хозяйственной деятельностью предприятий гражданской авиации. Москва. 215 с.

[2] Бабаскин В.В., Королькова М.А. (2011). Пути повышения эффективности работы авиапредприятия. Санкт-Петербург. $80 \mathrm{c}$.

[3] Беленький А.С. (1992). Исследование операций в транспортных системах: идеи и схемы методов оптимизации планирования. Москва.

[4] П.Бусленко В.Н. (1977). Автоматизация имитационного моделирования сложных систем. Москва. 239 с.

[5] Горлач JI.В. (1990). Разработка методов и алгоритмов оперативного управления процессом подготовки воздушных судов к рейсу: автореф. дис. ... канд. тех. наук. Ленинград.

[6] Канарчук В.Е., Чигринец А.Д., Ленчевский В.Н. (1987). Средства обслуживания авиаперевозок: Справочник. Киев. $136 \mathrm{c}$.

[7] Колясников В.А. (2004). Совершенствование технологии функционирования наземных служб для обеспечения безотказной работы аэропортового предприятия: автореф. дис. ... канд. тех. наук. Санкт-Петербург. 24 с.

[8] Куклев Е.А. (1998). Методы математического моделирования систем. Санкт-Петербург. 116 с.

[9] Лисицин В.С., Смирнов Н.Н., Чинючин Ю.М. (1985). Автоматизация производственных процессов технической эксплуатации летательных аппаратов. Москва. 248 с.

[10] Литвиненко А.Е. (1988). Моделирование производственных процессов в автоматизированных системах управления гражданской авиации. Учебное пособие. Киев. 72 с.

[11] Принципы организации погрузочно-разгрузочных работ воздушных судов. ИАТА. 1991. 230 с.

[12] Резер С.М. (1985). Взаимодействие транспортных систем. Москва. 246 с.

[13] Русинов И.Я. (1971). Механизация наземного обслуживания воздушных перевозок. Москва. 252 с.

[14] Советов Б.Я., Яковлев С.А. (1985). Моделирование систем: Учебник для вузов по спец. «Автоматизированные системы управления». Москва. $271 \mathrm{c}$.

[15] Яшкин А.Р., Павлов А.JI. (1983). Организация управления наземными службами аэропортов. Теоретические основы оптимизации функционирования. Учебное пособие. 75 с.

(С) Д. В. Мединський, Д. Л. Маляренко Дата надходження статті до редакції: 11.12.2020

Дата затвердження статті до друку: 19.12.2020 